\begin{tabular}{|l|l|l||}
\hline \multicolumn{2}{|c|}{ PublisherInfo } \\
\hline \hline PublisherName & $:$ & BioMed Central \\
\hline \hline PublisherLocation & $:$ & London \\
\hline \hline PublisherImprintName & $:$ & BioMed Central \\
\hline \hline
\end{tabular}

\title{
2004 US life science funding
}

\begin{tabular}{|l|l|l||}
\hline \multicolumn{2}{|c||}{ ArticleInfo } \\
\hline \hline ArticleID & $:$ & 4818 \\
\hline \hline ArticleDOI & $:$ & $10.1186 /$ gb-spotlight-20030722-01 \\
\hline \hline ArticleCitationID & $:$ & spotlight-20030722-01 \\
\hline \hline ArticleSequenceNumber & $:$ & 170 \\
\hline \hline ArticleCategory & $:$ & Research news \\
\hline ArticleFirstPage & $:$ & 1 \\
\hline \hline ArticleLastPage & $:$ & 4 \\
\hline \hline & & RegistrationDate : 2003-7-22 \\
ArticleHistory & $:$ & OnlineDate \\
\hline \hline ArticleCopyright & $:$ & BioMed Central Ltd2003 \\
\hline \hline ArticleGrants & $:$ & \\
\hline \hline ArticleContext & $:$ & 130594411 \\
\hline \hline
\end{tabular}


Ted Agres

Email: tedagres@lycos.com

In contrast to last year's federal budget boondoggle, which saw funding increases for key life science agencies frozen for nearly 5 monthswhile partisan politics held sway, rapid progress is being made to pass budgets for fiscal year (FY) 2004, which begins October 1.

During the past 2 weeks, the House of Representatives approved appropriations for the National Institutes of Health (NIH) and the Department of Homeland Security (DHS), which includes funding for Project BioShield. Last week, a House appropriations subcommittee approved a $6.2 \%$ increase for the National Science Foundation (NSF), nearly twice the increase requested by the White House. NIH and BioShield funding in the House match the administration's requests.

The Senate this week will take up floor debate on DHS, and the full House Appropriations Committee will consider the NSF funding measure. But floor debate in the House on NSF and floor action in the Senate on NIH, which is expected to be contentious, will probably have to wait until Congress returns from its August recess. Still, observers take the progress of various funding bills so far as a welcome sign.

"With one-party control of the House, Senate, and the White House, and because the budgetary situation is so tight, [republicans] have decided to exert party discipline," said Patrick White, legislative relations director for the Federation of American Societies for Experimental Biology (FASEB). "The result is you see the appropriations bills moving."

On July 10, the House voted 215 to 208 to approve HR 2660, the Labor, Health and Human Services (HHS) funding measure that would give NIH \$27.66 billion. This amount matches the White House's budget request and is a $2.5 \%$ increase over the current fiscal year. "The fact that NIH is not faring as well as we had hoped is not a partisan matter," White said. Many appropriations subcommittee members would like to put more money into research, he said, but "they're forced to write and pass bills under the tightest allocations to their subcommittees that we've seen in years."

The Senate Labor, HHS, Education and Related Agencies Subcommittee has allocated NIH \$27.98 billion in its bill ( $\mathrm{S}$ 1356). This is a 3.7\% increase of $\$ 1.0$ billion over the current year's appropriation and $\$ 318.6$ million more than the White House requested. Sen. Dianne Feinstein (D-Calif.) plans to introduce an amendment that would give NIH an additional $\$ 1.3$ billion, bringing the total to $\$ 29.28$ billion, an 8.5\% increase over FY 2003 levels.

That move would be in line with calls by research advocates to continue the NIH budget doubling effort. FASEB and other associations are urging a 10\% increase for NIH next year and double-digit increases thereafter to maintain the research-funding momentum.

On July 16, the House overwhelmingly approved the Project BioShield Act of 2003 (HR 2122), the White House's plan to accelerate development and production of new vaccines and countermeasures against bioweapons. The measure would provide some $\$ 5.6$ billion over the next 10 years to develop and produce vaccines and therapeutics against a range of potential biological and chemical weapons. Days earlier, the House had approved \$29.4 billion for overall DHS funding (HR 2555), including \$890 million next year for BioShield. 
The Bush administration wants BioShield to have a mandatory, permanent funding stream to spur research and development of new vaccines and therapeutics. But numerous congressmen have balked at the idea, saying that a mandatory funding mechanism would be an abdication of their oversight responsibility. The final House bill compromises on the issue, authorizing discretionary spending at the amounts requested but requiring the administration to provide new, additional reporting on how the funds are being used.

In the Senate, BioShield is complicated. The Senate version of legislation authorizing BioShield (S 15) includes the White House's request for permanent funding authority and was approved by the Health, Education, Labor and Pensions Committee in March. But Sen. Robert Byrd (D-W.Va.) has blocked the bill from floor action largely because he objects to the mandatory funding provision. The full Senate began floor debate on the DHS appropriation on Monday. BioShield funds will not be included unless mandatory funding is approved.

But it was the NSF that got the best news of all this month. The House Appropriations Veterans Affairs, Housing and Urban Development (VA/HUD) Subcommittee approved a 6.2\% increase of \$329 million, bringing NSF's total funding to $\$ 5.64$ billion for FY 2004. This is \$158 million more than the administration had requested. "The House VA/HUD Subcommittee was far more generous to NSF than we would have hoped," said FASEB's Pat White.

Research and related activities would grow by $\$ 200$ million from the White House request of $\$ 4.11$ billion to $\$ 4.31$ billion. The Major Research Equipment accountwould decline to $\$ 192$ million from the requested \$202 million, but it is still a \$44 million increase, or nearly 30\%, over FY 2003.

In a further surprise move, the NSF budget includes $\$ 12$ million to begin construction of two facilities in the long-delayed National Ecological Observatories Network (NEON). Legislators, however, want to be sure NEON does not duplicate other existing projects before releasing more funds. "It was a pleasant surprise," said Sam Rankin, chairman of the Coalition for National Science Funding. "Maybe Congress is finally convinced that this is a project that needs to be started."

The full House Appropriations Committee took up the spending bill Monday, but floor debate is not expected until September. The Senate has yet to complete its version of the bill.

\section{References}

1. Agres T: Final 2003 funding The Scientist, February 19, 2003., [http://www.the-scientist.com/news/ 20030219/02/] 
2. Agres T: Funding 2004 The Scientist, February 4, 2003., [http://www.the-scientist.com/news/ 20030204/04/]

3. Agres T: Budget wrangling begins The Scientist, June 27, 2003., [http://www.the-scientist.com/news/ 20030627/03/]

4. Agres T: Bioshield moving forward The Scientist, May 16, 2003., [http://www.the-scientist.com/ news/20030516/06/]

5. Agres T: Microbiologists wanting The Scientist, June 16, 2003., [http://www.the-scientist.com/news/ 20030616/04/]

6. Agres T: NSF tools review The Scientist, April 23, 2003., [http://www.the-scientist.com/news/ 20030423/03/]

7. Russo E: Brightening NEON's prospects The Scientist, March 27, 2003., [http://www.thescientist.com/news/20030327/02/]

This PDF file was created after publication. 